\title{
Job satisfaction and career persistence of beginning teachers
}

\author{
Wei-Cheng J. Mau, Randy Ellsworth and Donna Hawley
}

\begin{abstract}
Purpose - The purpose of this research is to examine career persistence and job satisfaction of beginning teachers. Design/methodology/approach - Four hundred and fifty-one tenth grade students from a nationally representative sample, who aspired to be teachers, were examined over a ten year period regarding their career choices. Students who persisted in teaching were compared to students who did not persist with regard to job satisfaction. A job satisfaction model was tested using clusters of variables as guided by Social Cognitive Career Theory (SCCT). Findings - Students who persisted in teaching were significantly more satisfied than both those who did not persist and those with non-teaching careers. Beginning teachers were more satisfied with their jobs than those in other occupations. Teachers who had teaching licenses also reported being more satisfied than those who did not have licenses. The social-contextual factors, i.e. race, socioeconomic status, teaching license, parents' education, and occupation were among the best predictors of job satisfaction. Research limitations/implications - We did not measure self-efficacy directly. Instead, we used the separate yet highly correlated constructs, self-concept and locus of control, to represent the self-efficacy. For improvement, further research may use a more direct measure of self-efficacy. Practical implications - Awareness of key factors influencing persistence in teaching career and job satisfaction identified in this study would provide school administrators with a sound basis for identifying students who are likely to persist in becoming teachers, and in retaining satisfied teachers. Originality/value - Findings of this study should assist educational administrators to better understand factors related to selection and retention of beginning teachers.
\end{abstract}

Keywords: Career development, Teachers, Job satisfaction

The shortage of teachers, especially in some areas of high demand, is increasing at an alarming rate (US Department of Education, 2002). The most troubling trend is that the proportion of minority teachers has been decreasing, whereas the proportion of minority students in USA schools has been increasing (Place, 1997). One way to address the teacher shortage problem is to identify individuals potentially seeking teaching careers, and examine their persistence and job satisfaction with their chosen career. Recent research seems to indicate that recruitment is not the primary problem in staffing the nation's schools but it is more a matter of teacher retention (Cochran-Smith, 2004; Ingersoll, 2001), which is a prime responsibility of school administrators. Extensive research has identified the relationship of job satisfaction to work-related behaviors such as retention, attitudes toward work, and commitment to the organization. Satisfied workers are less likely to leave their jobs and are more committed to their organizations than are dissatisfied workers (Dawis and Lofquist, 1984). Teacher job satisfaction and potentially associated higher retention rates are often of concern to educational administrators as they consider which steps they can take to help address the shortage of teachers. Thus, the purpose of the present study was to examine career persistence and job satisfaction of beginning teachers, using a nationally representative sample of tenth grade students who were longitudinally studied for ten years regarding their career choices.

The meaning of job satisfaction varies (Fritzsche and Parrish, 2005), from simply the feelings a worker has about his/her job (Smith et al., 1969) to the following definition: "an affective reaction to a job, that results from the incumbent's comparison of actual outcomes with those that are desired" (Cranny et al., 1992, p. 1). The theoretical framework for most of the research on job satisfaction can be traced to the pioneering work of Herzberg et al. (1959). The Herzberg theory has often been linked to that of Maslow's Theory of Hierarchy of Needs. Briefly, this theory suggests that there are higher-order needs 
and lower-order needs - motivation and hygiene factors. Motivation factors are intrinsic satisfiers that are associated with higher-order needs such as achievement, recognition, responsibility, advancement, etc. Hygiene factors are extrinsic satisfiers that tend to be associated with lower-order needs such as working conditions, pay, status, etc. The presence of extrinsic satisfiers does not lead to true job satisfaction, but their absence can lead to dissatisfaction. Most studies (e.g., Bein et al., 1990; Place, 1997; Wu and Short, 1996) suggest that teachers place more emphasis on intrinsic satisfiers, but other studies suggest that a mix of intrinsic and extrinsic satisfiers are the best predictors of teacher job satisfaction (Dvorak and Phillips, 2001). This study hypothesized that teachers who persisted in their teaching careers are influenced more by intrinsic factors such as opportunities for advancement, use of training and education, etc. than extrinsic factors such as pay or job security.

Research on teacher job satisfaction can be classified into three groups:

(1) Demographic factors (e.g. Mueller et al., 1999; Vegas et al., 2001; Vance, 1981);

(2) School climate and organizational culture, for example, adequate resources (Firestone and Pennell, 1993; Ma and MacMillan, 1999), student quality and performance (Ostroff, 1992; Vance, 1981), collegial support (Hart, 1994), leadership style (Bogler, 2001), and the quality of working relationships (Dinham, 1995); and

(3) Teachers' psychological characteristics, for example, motivation (Mertler, 2002), locus of control (Bein et al., 1990), and self-efficacy (Wu and Short, 1996).

Most studies of job satisfaction have been based on graduates who began teaching prior to 1990 . Also in recent years, changes in teacher supply and demand, and factors that influence job satisfaction may change with time and reflect facets of the changing culture (Shreeve et al., 1988). Lack of systematic inquiries and extended follow-ups on this issue appear to be critical and can be best addressed using largescale surveys involving nationally representative samples. To the best of our knowledge, this study represents the first attempt to use social cognitive theory (Lent et al., 1994) as a framework to examine job satisfaction and career persistence of high school students aspiring to teaching careers.

Research has shown the strength of young people's career aspirations in predicting their subsequent career behaviors (Hansen, 2005; Mau, 2003; Mau and Bikos, 2000; Mau and Mau, 2006). Studies have indicated that decisions to become teachers can be traced back to middle school years (Lee et al., 2001; Page and Page, 1984) and likely peak at ages 15 to 16 (Page et al., 1980). Tracy et al. (2005) suggest that high school years are a time of focus for counseling interventions because students' career interests begin to stabilize. Therefore, the present study focused on tenth grade students who said they wanted to be teachers, and the longitudinally-examined factors that influenced their persistence and satisfaction in their teaching careers.

In this study, we utilized social cognitive career theory (SCCT) as our conceptual framework to understand factors influencing high school students to persist in aspirations of teaching careers and the job satisfaction of beginning teachers. This model concerns itself with the effects of self-efficacy beliefs, expected outcomes, and goal mechanisms, and how these variables interrelate with other important aspects of persons (e.g., sex, race), their contexts, and learning experiences to help shape the contours of educational and career development (Lent, 2005). According to the SCCT (Lent et al., 1994), personal career-related behavior is influenced by four aspects: behaviors; self-efficacy beliefs; outcome expectations; and goals, in addition to genetically determined characteristics. Goals are considered the key organizational processes that influence an individual's thoughts and behaviors (Schutz et al., 2001). Self-efficacy beliefs refer to "people's judgments of their capabilities to organize and execute a course of action required to attain designated types of performances" (Bandura, 1986, p. 391). Self-efficacy serves as a generative mechanism through which individuals integrate and apply their existing cognitive, behavioral, and social skills to a task. SCCT posits that self-efficacy affects thought patterns and partly 
determines individuals' actions and their decisions to engage in a task, to put forth effort, and to persevere under failure (Bandura, 1986).

According to Lent (2005), persistence can be seen both as a matter of choice stability, involving the decision to remain at a particular activity (e.g., educational tasks, job positions, or careers) and also as an indicator of how well an individual is performing at either required or chosen endeavors. From the perspective of educational and work environments, persistence is considered a sign of performance adequacy because it is assumed that competent performers will persist longer, enabling attainment of educational milestones and job tenure. Lent and Brown (2003) have attempted to extend the SCCT to include the affect domain - educational or vocational satisfaction. It has been found that personal goals have been empirically linked to satisfaction outcomes. "People are more likely to make progress on their valued goals and to be satisfied to the extent that they feel self-efficacious, hold favorable outcome expectations, and have access to environmental supports and resources relevant to the pursuit of their goals" (Lent, 2005, p. 122).

One of the main interests of this study was to determine if there are race and sex differences in teaching persistence and job satisfaction. School district personnel and teacher educators have continued to express their concern about the critical underrepresentation of minority groups in the teaching profession (Gordon, 1993). As the nation's school population becomes more diverse, the teaching force becomes increasingly homogeneous (Dilworth, 1990). Mueller et al. (1999) have argued that job satisfaction is a function of homogeneity of members in a group. They suggest that race and gender are two of the most crucial characteristics in the formation of groups. Thus, a study of minority teachers' job satisfaction is essential. Studies have shown that male teachers are less satisfied than female teachers (Ma and MacMillan, 1999). Men were also more likely to have higher attrition rates than women during the first five years of teaching.

Specifically, this study investigated whether teacher job satisfaction is a function of race or sex, career persistence, educational training, and parents' occupations using a social-cognitive model as a conceptual framework for variable selection and organization. In the era of demand for effectiveness and accountability under budgetary constraints, educational administrators must focus on administrative policies and practices that effect recruitment and retention of beginning teachers. The first step in ensuring accountability and efficient outputs of educational delivery systems is to gain a clear understanding of the characteristics of students likely to enter and persist in the teaching profession (Mau and Mau, 2006) and how these characteristics contribute to the job satisfaction of entering teachers. Findings of this study should assist educational administrators to better understand factors related to selection and retention of beginning teachers.

\section{Method}

Participants

The data used in this study were based on the National Educational Longitudinal Survey of 1988 (NELS: 88), which consisted of a base year (1988), first follow-up (1990), second follow-up (1992), third follow-up (1994), and fourth follow-up (2000). The base-year survey was comprised of a nationally representative sample of 24,599 students selected from 1,052 middle schools (public, N 1/4 815 and private, $\mathrm{N} 1 / 4237$ ) in the USA. The sample was stratified by school size, urban versus rural, region, and percentage of minority students (National Center for Educational Statistics, 1994). The sample was refreshed with additional students in both the first follow-up (10th-grade, $\mathrm{N} 1 / 420 ; 840$ ) and second follow-up (12th-grade, $\mathrm{N} 1 / 421 ; 188)$ due to participant attrition. The third follow-up $(\mathrm{N} 1 / 414 ; 915)$ took place in the spring of 1994 , when most sample members had been out of high school for two years. The fourth follow-up took place in 2000, the year in which most sample members turned 26 years old, and consisted of 12,144 participants (5,725 men, 6,326 women and 93 were not identified; 833 Asian Americans, 1,594 Hispanic Americans, 1,151 African Americans, 8,274 White Americans, and 157 Native Americans, and 135 were not identified). 
We used data from the first follow-up and third follow-up to examine the role of persistence, and from the first follow-up and fourth follow-up to examine the outcome of job satisfaction.

The analyses were based on weighted samples created to adjust for the oversampling bias, which redistributed the observations to represent the distribution in the population (NCES, 1997). Since statistical procedures generally compute regression coefficients based on simple random sample assumptions, the standard errors must be adjusted with design effects using appropriate variance estimation procedures, which take into account the complex sampling procedures used in the NELS: 88 survey (Curtin et al., 2002). AM Statistical Software was used in this study to adjust for standard errors for significant tests (American Institutes for Research, 2003).

\section{Instrument}

The following independent variables were used in this study:

(1) Demographic variables:

- Four major race groups - Asian, Hispanic, Black, and White American. Insufficient numbers of Native Americans included in the sample precluded them from the statistical analysis.

(2) School and cognitive variables:

- Academic proficiency. Academic proficiency was measured by a composite score of two cognitive tests developed by the Educational Testing Service (40 items for mathematics and 21 items for reading). The reading test consisted of five short passages followed by comprehension and interpretation questions. The mathematics test consisted of quantitative comparisons and other questions. A standardized composite score (M $1 / 450$, SD $1 / 410$ ) was used. Coefficient alpha reliabilities on the eighth-grade sample for the math and reading tests were 0.90 and 0.84 , respectively. Based on the Mantel-Haenszel odds-ratio analyses (Holland and Thayer, 1986), there was little evidence of differential item functioning for either gender or racial/ethnic group. Factor analytic results supported the discriminant validity of the three content areas. Convergent validity also was indicated on the hypothesized factors. More detailed psychometric information can be found in the NCES (1991) Psychometric Report for the NELS: 88 Base Year Test Battery Teaching License and Credentials. Students also indicated if they received a professional teaching license since graduating from high school.

(3) Parental/familial variables:

- Socioeconomic Status (SES). SES is a composite score that was based on parents' education, occupation, and family income. Parental education ranged from 1 (did not finish high school) to 6 ( $\mathrm{PhD}, \mathrm{MD}$, or other postgraduate degree). Occupational data were coded using the Duncan SEI scale. Family income data were based on the total family income in 1987. Income level ranged from 1 (none) to 15 (\$200,000 or more). Each component was standardized with a mean of 0 and a standard deviation of 1 . All components were averaged, yielding the SES composite. The composite scores were then recoded into quartiles (see NCES, 1990).

- Perceived parental expectations. This variable was measured by the survey question: "How far in school do you think your father and your mother want you to get?" Responses were coded from 1 to 6 as follows: (1) "won't finish high school"; (2) "will graduate from high school"; (3) "will go to vocational school"; (4) "will attend college"; (5) "will graduate from college"; and (6) "will attend a higher level of school after graduating from college". Students recorded their perceptions for each parent separately. A total score was used. 
- Parental school involvement. This variable was measured by a survey question: "In the first half of the school year, how often did either of your parents or guardians do any of the following?" Responses were: attend a school meeting; attend a school event in which you participated; phone a teacher or counselor; and act as a volunteer at your school. The Cronbach's Alpha based on 11,150 tenth graders was estimated at 0.65 .

- Parental academic involvement. This variable was measured by the survey question: "In the first half of the school year, how often have you discussed the following with either or both your parents or guardians?" Responses were: selecting course or program at school; school activities or events of particular interest to you; things you have studied in class; your grades; transferring to another school; plans and preparation for the ACT or SAT tests; and going to college. The Cronbach's Alpha based on 13,514 tenth graders was estimated at 0.97 .

- Number of siblings. This variable was derived from the base-year parent survey questionnaire and indicated the participant's household composition.

- If mother/father's occupation was a teacher. This variable was derived from a survey question that reported parents' occupation.

(4) Self-efficacy variables:

- Three self-evaluation measures - self-concept, locus of control, and academic selfefficacy - were used to indicate variable. In a meta-analysis of studies published in ten psychology journals, Judge et al. (2002) indicated that the relationship among the self-esteem, locus of control, and generalized self-efficacy are highly intercorrelated. Not only are they conceptually similar traits, but findings from many factor analyses suggest that they load on a first-order, single-factor model. For example, Erez and Judge (2001) estimated three confirmatory analysis models across independent samples and found that a single-factor model fit the data well. The average loadings of the three traits on the higher-order factor were self-esteem (0.91), locus of control (0.74), and generalized self-efficacy (0.81).

- Self-concept. This variable was measured by a composite score consisting of seven self-concept items (e.g., I feel good about myself). The Cronbach's Alpha estimate based on 13,514 tenth graders was 0.95 .

- Locus of control. This variable was measured by a composite score derived from six locus of control items (e.g., I don't have enough control over the direction my life is taking). The Cronbach's Alpha estimate based on 13,514 tenth graders was 0.94 .

- Academic self-efficacy. This variable was measured by five survey questions (e.g. math is one of my best subjects, English is one of my best subjects). The Cronbach's Alpha estimate based on 11,990 tenth graders was 0.75 .

(5) Motivational factors:

- Work orientation. This variable, expressed in percentages, measured the importance of work. It consisted of three questions involving being successful in work, having lots of money, and being able to find steady work. The Cronbach's Alpha estimate based on 12,963 tenth graders was 0.80 .

- Persistence. This variable was measured based on the status of students' expected occupation at age 30 . The variable was further coded as follows: (1) Persisters: students who aspired to a teaching career both at tenth grade and ten years later, and (2) Switchers: students who aspired to a teaching career at tenth grade but changed their focus to non-teaching careers ten years later. 
The dependent variable of the satisfaction factor study was measured by a survey question: Would you say you are/were satisfied or dissatisfied with your job as a whole? Measures of extrinsic job fulfillment consisted of survey questions on satisfaction or dissatisfaction with pay, benefits, and job security. Measures of intrinsic job satisfaction consisted of work importance and challenge, opportunities for promotion and advancement, opportunities to use past training/education, and opportunities for further training/education.

\section{Data analyses}

The research questions proposed earlier were addressed by several separate statistical analyses. First, tenth graders who initially aspired to the teaching profession and persisted in each follow-up cohort were identified. Separate analyses of descriptive statistics and variance (ANOVA) were performed to provide further understanding of the nature of job satisfaction and persistence factors. A composite score was computed for each of the intrinsic, extrinsic, and overall job satisfaction measures. The level of significance was adjusted for multiple comparisons. Second, logistic analyses were performed to examine factors contributing to teaching persistence and job satisfaction. Logistic regression provides a test of probability that members of a specific group are more likely to report satisfaction in their job. As stated earlier, variable selection and entry into the model are guided by the social cognitive theory of career choice and aspiration. Predictors were entered in blocks simultaneously, with demographic variables entered first, then school variables, followed by familial variables, self-efficacy variables, and motivational variables.

\section{Results}

Job satisfaction was investigated in two ways: one was based on the full sample of the fourth follow-up ( $\left.1 \frac{1}{4} 12 ; 144\right)$, and the other was based on 398 teachers in the fourth follow-up.

Table I contains a summary of results from analyses of variance (ANOVAs) on job satisfaction by sex, race, teaching persistence, license, and mother's and father's occupations based on the full sample. Results suggest that there are significant differences as a function of sex, race, persistence in teaching, and license status. Men ( $M \frac{1}{4}$ 5:5), in general, were more satisfied than women ( $M \frac{1}{4} 5: 1$ ) on the job. White Americans ( $M \frac{1}{4}$ 5:5) were significantly more satisfied than Asian Americans ( $M 1 / 4$ 5:0), Hispanic Americans ( $M \frac{1}{4}$ 5:0), and Black Americans ( $M 1 / 4$ 4:7). Teachers who persisted in pursuing teaching careers since high school ( $M$ 1 $1 / 4$ 6:2) were significantly more satisfied than those who did not persist ( $M$ 1 $1 / 4: 3$ ) or the general population ( $M \frac{114}{4}$ :3). Level of significance was adjusted for multiple comparisons.

Table II provides a summary of ANOVA results drawn from the subsample that consisted of teachers (n $1 / 4$ 398). Significant differences were found in overall satisfaction as a function of race, persistence, and license status; in intrinsic satisfaction as a function of persistence and license status, and in extrinsic satisfaction as a function of the father's occupation. Asian American teachers (M 1/4 6:2) and Hispanic American teachers ( $M 1 / 46: 2$ ) were significantly more satisfied than Black American teachers ( $M$ $1 / 4$ 5:4). Teachers who have teaching licenses ( $\left.M \frac{1}{4} 6: 0\right)$ were more satisfied than teachers without licenses (M 1/4 5:4). Of the 398 teachers surveyed in this study, 16 percent had a mother who was also a teacher. Although they ( $M \frac{1}{4} 6: 0$ ) were slightly more satisfied than those whose mother was not a teacher ( $M$ 1/4 $5: 8)$, the difference was not statistically significant. Only 7 percent of teachers had a father who was also a teacher. They scored significantly higher on extrinsic satisfaction ( $M \frac{114}{4} 2: 63$ ) than those teachers whose father was not a teacher ( $\left.M \frac{1}{4} 2: 25\right)$. Teachers who persisted ( $M \frac{1}{4} 3: 8$ ) were significantly more intrinsically satisfied than those individuals who did not persist (M 1/4 3:1) and who were non-teachers (M 1/4 3:0). There was no significant difference in extrinsic factors. 


\begin{tabular}{|c|c|c|c|c|c|c|}
\hline \multirow{2}{*}{$\begin{array}{l}\text { Sample characteristics } \\
\text { (Weighted } N \text { ) }\end{array}$} & \multicolumn{2}{|c|}{$\begin{array}{l}\text { Overall } \\
\text { satisfaction }\end{array}$} & \multicolumn{2}{|c|}{ Intrinsic } & \multicolumn{2}{|c|}{ Extrinsic } \\
\hline & $\mathrm{M}$ & SD & $\mathrm{M}$ & $\mathrm{SD}$ & $\mathrm{M}$ & SD \\
\hline a. Men $(n=5,905)$ & $55^{\mathrm{b}}$ & 1.82 & $3.1^{\mathrm{b}}$ & 1.24 & $2.4^{\mathrm{b}}$ & 0.85 \\
\hline b. Women $(n=5,859)$ & 5.1 & 2.00 & 2.9 & 1.32 & 22 & 0.92 \\
\hline a. $A \operatorname{sian}(n=443)$ & 5.0 & 2.00 & 2.8 & 1.35 & 22 & 0.90 \\
\hline b. Hispanic $(n=1,298)$ & 5.0 & 2.00 & 2.9 & 1.32 & 2.1 & 0.99 \\
\hline c. Black $(n=1,462)$ & 4.7 & 2.16 & 2.7 & 1.42 & 2.0 & 1.00 \\
\hline d. White $(n=8,351)$ & $55^{a, b, c}$ & 1.80 & $3.1^{\mathrm{a}, \mathrm{c}}$ & 1.24 & $2.4^{\mathrm{a}, \mathrm{b}, \mathrm{c}}$ & 0.83 \\
\hline a. Persister $(n=73)$ & $62^{b, d}$ & 0.97 & $3.8^{\mathrm{b}, \mathrm{c} d \mathrm{~d}}$ & 0.49 & 2.4 & 0.70 \\
\hline b. Switcher $(n=382)$ & 5.3 & 1.85 & 3.1 & 1.30 & 2.3 & 0.82 \\
\hline c. Newcomer $(n=278)$ & $58^{\mathrm{d}}$ & 1.34 & $3.5^{\mathrm{b}, \mathrm{d}}$ & 0.84 & 2.3 & 0.76 \\
\hline c. Non-teacher $(n=8,838)$ & 5.3 & 1.87 & 3.0 & 1.28 & 2.3 & 0.87 \\
\hline Teacher with license $(n=310)$ & $58^{\mathrm{d}}$ & 1.32 & $3.6^{b, d}$ & 0.78 & 22 & 0.78 \\
\hline Non-teacher with license $(n=196)$ & 5.6 & 1.46 & $3.4^{\mathrm{d}}$ & 0.94 & 2.3 & 0.87 \\
\hline Teacher without license $(n=142)$ & $5.7^{\mathrm{d}}$ & 1.71 & $3.5^{\mathrm{d}}$ & 1.03 & 2.3 & 0.89 \\
\hline Non-teacher without license ( $n=1,115$ ) & 53 & 1.91 & 3.0 & 1.30 & 2.3 & 0.89 \\
\hline Mother is a teacher ( $n=622$ ) & 55 & 1.76 & 3.1 & 1.28 & $2.4^{\mathrm{b}}$ & 0.82 \\
\hline Mother is not a teacher ( $n=10,890)$ & 5.3 & 1.91 & 3.0 & 1.28 & 2.3 & 0.89 \\
\hline Father is a teacher $(n=222)$ & 5.4 & 1.90 & 3.0 & 1.31 & 2.4 & 0.83 \\
\hline Father is not a teacher $(n=11246)$ & 5.3 & 1.90 & 3.0 & 1.28 & 2.3 & 0.89 \\
\hline
\end{tabular}

Note: Superscripts represent groups that scored significantly different from the contrast group

Table I.

Job satisfaction by sex, race, teaching

persistence, teaching credentials, and parents' occupations

\begin{tabular}{|c|c|c|c|c|c|c|}
\hline \multirow{2}{*}{$\begin{array}{l}\text { Sample characteristics } \\
\text { (Weighted } N \text { ) }\end{array}$} & \multicolumn{2}{|c|}{$\begin{array}{c}\text { Overall } \\
\text { satisfaction }\end{array}$} & \multicolumn{2}{|c|}{ Intrinsic } & \multicolumn{2}{|c|}{ Extrinsic } \\
\hline & $M$ & $S D$ & $M$ & $S D$ & $M$ & $S D$ \\
\hline a. Male teachers $(n=103)$ & 5.69 & 1.53 & 3.46 & 0.94 & 2.23 & 0.82 \\
\hline b. Female teachers $(n=294)$ & 5.90 & 1.18 & 3.61 & 0.73 & 2.29 & 0.74 \\
\hline a. Asian teachers $(n=7)$ & $6.20^{\circ}$ & 0.96 & 3.72 & 0.75 & 2.49 & 0.62 \\
\hline b. Hispanic teachers $(n=23$ ) & $6.17^{c}$ & 0.99 & 3.78 & 0.58 & 2.39 & 0.68 \\
\hline c. Black teachers $(n=20)$ & 5.44 & 1.41 & 3.37 & 0.98 & 2.07 & 0.75 \\
\hline d. White teachers ( $n=345$ ) & 5.83 & 1.30 & 3.56 & 0.79 & 2.27 & 0.77 \\
\hline a. Persisters $(n=73)$ & $6.2^{\mathrm{b}}$ & 0.97 & $3.80^{\mathrm{b}}$ & 0.49 & 2.4 & 0.70 \\
\hline b. Switchers $(n=382)$ & 5.3 & 1.85 & 3.10 & 1.30 & 2.3 & 0.82 \\
\hline a. Teaching license $(n=307)$ & $5.96^{\mathrm{b}}$ & 1.15 & $3.64^{\mathrm{b}}$ & 0.68 & 2.32 & 0.74 \\
\hline b. No teaching license $(n=91)$ & 5.45 & 1.50 & 3.33 & 1.07 & 2.11 & 0.82 \\
\hline a. Mother is a teacher $(n=62)$ & 6.01 & 1.08 & 3.67 & 0.64 & 2.34 & 0.75 \\
\hline b. Mother is not a teacher $(n=335)$ & 5.81 & 1,32 & 3.55 & 0.82 & 2.26 & 0.76 \\
\hline a. Father is a teacher $(n=26)$ & 6.23 & 1.54 & 3.59 & 0.92 & $2.63^{3}$ & 0.69 \\
\hline b. Father is not a teacher $(n=369)$ & 5.81 & 1.27 & 3.57 & 0.79 & 2.25 & 0.76 \\
\hline
\end{tabular}

Note: Superscripts represent groups that scored significantly different from the contrast group
Table II.

Teaching job satisfaction by sex, race, teaching persistence, teaching credentials, and parents

Table III summarizes the results of logistic analysis. Variable selection and entry into the model are guided by SCCT. Results of adjusted Wald tests showed significant improvement in the fit of the model as the following variables were added to the model: demographic variables $[F(4,327)=2: 20, p<0.068]$, school/cognitive variables $[F(6,313=2: 99, p<0.007]$, parental/familial variables $[F(13,252=40: 32, p<$ $0.000]$, self-efficacy variables $[F(17,239=28: 40, p<0.000]$, and motivational variables $[F(19,200=52: 93$, $p<0.000$ ]. Results suggested that race, academic proficiency, teaching license, socioeconomic status, parental educational level, and if mother was a teacher were among the best predictors of job satisfaction. $\operatorname{Exp}(ß)$ is the predicted change in odds for a unit increase in the predictor. When $\operatorname{Exp}(ß)$ is less than 1 , increasing values of the variable correspond to decreasing odds of the event's occurrence. When $\operatorname{Exp}(ß)$ is greater than 1, increasing values of the variable correspond to increasing odds of the event's 
occurrence. Other factors being equal, Black teachers $(\operatorname{Exp}(ß)=0: 11)$ were less likely to report satisfaction with their jobs than White teachers. Certified teachers $(\operatorname{Exp}(\beta)=4: 60)$ were more likely to report satisfaction than non-certified teachers. Academic proficiency at the tenth grade negatively predicted job satisfaction. Whereas socioeconomic status and mother being a teacher positively predicted teachers' job satisfaction, the parental educational attainment negatively predicted the job satisfaction of teachers.

\begin{tabular}{|c|c|c|c|c|c|c|}
\hline & \\
\hline & Variable & B & $\mathrm{SE}$ & $t$ & $p$ & $\operatorname{EXP}(B)$ \\
\hline & $\begin{array}{l}\text { Demographic factors } \\
\text { Male } \\
\text { Asian } \\
\text { Hispanic } \\
\text { Black }\end{array}$ & $\begin{array}{r}-1.00 \\
0.90 \\
1.03 \\
-2.23\end{array}$ & $\begin{array}{l}0.60 \\
1.22 \\
1.13 \\
1.02\end{array}$ & $\begin{array}{r}-1.66 \\
0.74 \\
0.92 \\
-2.19\end{array}$ & $\begin{array}{l}0.10 \\
0.46 \\
0.36 \\
0.03\end{array}$ & $\begin{array}{l}0.37 \\
2.47 \\
2.81 \\
0.11\end{array}$ \\
\hline & $\begin{array}{l}\text { School factors } \\
\text { Licensed teachers } \\
\text { Academic proficiency }\end{array}$ & $\begin{array}{r}1.53 \\
-0.11\end{array}$ & $\begin{array}{l}0.75 \\
0.05\end{array}$ & $\begin{array}{r}2.04 \\
-2.32\end{array}$ & $\begin{array}{l}0.04 \\
0.02\end{array}$ & $\begin{array}{l}4.60 \\
0.90\end{array}$ \\
\hline & $\begin{array}{l}\text { Famital-social factors } \\
\text { Socioeconomic } \\
\text { Parents educational level } \\
\text { Sibling } \\
\text { Parent school involvement } \\
\text { Parent academic involvement } \\
\text { Mother is a teacher } \\
\text { Father is a teacher }\end{array}$ & $\begin{array}{r}1.84 \\
-1.37 \\
0.24 \\
-0.12 \\
-0.08 \\
1.87 \\
-0.29\end{array}$ & $\begin{array}{l}0.67 \\
0.53 \\
0.40 \\
0.19 \\
0.15 \\
0.94 \\
1.18\end{array}$ & $\begin{array}{r}2.74 \\
-2.59 \\
0.60 \\
-0.60 \\
-0.52 \\
1.98 \\
-0.24\end{array}$ & $\begin{array}{l}0.01 \\
0.01 \\
0.55 \\
0.55 \\
0.61 \\
0.04 \\
0.81\end{array}$ & $\begin{array}{l}6.32 \\
0.26 \\
1.27 \\
0.89 \\
0.92 \\
6.49 \\
0.75\end{array}$ \\
\hline & $\begin{array}{l}\text { Self-efficacy factors } \\
\text { Math selfefficacy } \\
\text { English self-efficacy } \\
\text { Locus of control } \\
\text { Self-concept }\end{array}$ & $\begin{array}{r}0.06 \\
-0.20 \\
0.12 \\
-0.05\end{array}$ & $\begin{array}{l}0.09 \\
0.18 \\
0.56 \\
0.61\end{array}$ & $\begin{array}{r}0.66 \\
-1.14 \\
0.21 \\
-0.08\end{array}$ & $\begin{array}{l}0.51 \\
0.25 \\
0.84 \\
0.94\end{array}$ & $\begin{array}{l}1.06 \\
0.82 \\
1.12 \\
0.95\end{array}$ \\
\hline \multirow{2}{*}{$\begin{array}{l}\text { Table III. } \\
\text { Logistic regression: } \\
\text { predictors of teacher job } \\
\text { satisfaction }\end{array}$} & $\begin{array}{l}\text { Motivational factors } \\
\text { Work orientation } \\
\text { Persist in teaching aspirations }\end{array}$ & $\begin{array}{l}0.56 \\
0.01\end{array}$ & $\begin{array}{l}1.25 \\
0.02\end{array}$ & $\begin{array}{l}0.45 \\
0.74\end{array}$ & $\begin{array}{l}0.66 \\
0.46\end{array}$ & $\begin{array}{l}1.75 \\
1.01\end{array}$ \\
\hline & \multicolumn{6}{|c|}{$\begin{array}{l}\text { Notes: Variables were entered in blocks based on SCCT model; Overall model evaluation (Wald test) } \\
F(19,200)=52.93, p<0.000\end{array}$} \\
\hline
\end{tabular}

\section{Discussion}

The purpose of this study was to examine job satisfaction of beginning teachers and factors influencing their satisfaction. Findings of this study showed that a higher percentage of teachers (92 percent) were satisfied with their work. This finding is very similar to a recent national Gallop Poll surveys (Fritzsche and Parrish, 2005), which reported that 90 percent of employed Americans were generally satisfied with their job. Findings also suggested that there were significant differences in overall job satisfaction among teachers in regard to their racial background. African American teachers were significantly less satisfied than other racial ethnic groups. This finding is consistent with previous studies conducted more than a decade ago (e.g., Greenhaus et al., 1990; Tuch and Martin, 1991). Both studies suggest that the low job satisfaction of African Americans is due to the low-paying and less-stable jobs that African Americans tend to have. Considering that African American teachers in the present study did not differ much from White American teachers relative to the work environment and pay scale, other factors contributed to the sources of job satisfaction and deserve further research attention.

Licensure is important in any profession that emphasizes accountability of service provided. Licensure processes ensure that teachers possess necessary skills and knowledge to be successful in the workplace. Our study has shown that teachers who were properly licensed were more likely to report 
satisfaction than those who did not have any license. This data would provide administrators with additional insight regarding the lack of satisfaction of some unlicensed teachers.

Another focus of this study was to investigate if students who persisted in teaching aspirations were more likely to be satisfied with their work. For ten years, 451 tenth graders who initially aspired to a teaching career were tracked. Ninety eight students (22 percent) out of 451 became teachers ten years later. Our findings suggest that, given other things being equal, students who persisted were significantly more satisfied than students who dropped out of the teaching pipeline. A previous study (Mau and Mau, 2006) pointed out that students who persisted in the teaching pipeline performed better on academic achievement, scored higher on locus of control, and came from a family that had a higher social economic status and a higher parental education level than students who did not persist. These factors can be included in career intervention designs for high school students who show initial interest in teaching careers.

Status attainment theory (Hotchkiss and Borow, 1996) suggests that parents' occupations influence their children's occupational attainment. Our study extended this assertion to suggest that teacher job satisfaction also is a function of parents' occupations. Mothers' teaching occupations significantly predicted their children's job satisfaction.

Putting it all together, our data suggest that the SCCT can adequately explain career persistence and job satisfaction of beginning teachers. As shown in Table III, the overall model evaluation (Wald test) suggested a significant fit of the model, $F(19,200 \mathrm{p} 1 / 452: 93, p, 0.000]$. In this model, demographic factors, school factors, and familial-social factors appear to be more potent in predicting job satisfaction than selfefficacy and motivational factors. Not all variables within each cluster have equal predicting power. For example, within the self-efficacy cluster, locus of control (ExpðbP $1 / 41: 12 \mathrm{P}$ increased the odds in predicting job satisfaction by 12 percent, whereas English self-efficacy (ExpðbP $1 / 4$ 0:82P decreased the odds in predicting job satisfaction by 18 percent. Neither self-concept nor math self-efficacy significantly predicted job satisfaction of beginning teachers. As is true of any study using general broad-based survey data, our study is limited to the survey questions available in the questionnaire. For example, since there was no specific measure of self-efficacy, we used locus of control and self-concept to represent the selfefficacy construct. Additionally, some data analyses were based on one-item responses only. Thus, special attention needs to be given to the interpretation of the results.

\section{Implications for administrative practice \\ Potential future teachers}

Findings of this study provide useful information for school administrators who may have significant impact on their students' career choices and plans. Awareness at the middle to high school level of sex, racial/ethnic differences, school variables, and parental influences that affect persistence and job satisfaction of beginning teachers is important as students are counseled about future careers. Students' racial background and school environment are key factors in persistence of teaching aspirations. Administrators and counselors are in positions where they can identify students who have teaching aspirations but are low in self-efficacy and help them to develop strategies for achieving their goals (Mau and Bikos, 2000). Informal support groups may be helpful in addressing problems of young men and ethnic minority students who show interest in teaching careers.

New teachers entering the profession

The early years of teaching are extremely critical to teacher job satisfaction and career persistence. Attrition from the teaching profession is the highest for young, less-experienced teachers (Heynes, 1988). School administrators should have some understanding of what factors can influence teachers' job satisfaction and the impact satisfaction can have upon their work lives. The findings of this study should provide educators and policy makers with a sound basis for identifying students who are likely to persist in becoming teachers, and in retaining satisfied teachers. 


\section{References}

American Institutes for Research (2003), AM Statistical Software, Beta Version 0.06.02, American Institutes for Research, Washington, DC.

Bandura, A. (1986), Social Foundations of Thought and Action: A Social Cognitive Theory, Prentice-Hall, Englewood Cliffs, NJ.

Bein, J., Anderson, D.E. and Maes, W.R. (1990), "Teacher locus of control and job satisfaction", Educational Research Quarterly, Vol. 14 No. 3, pp. 7-10.

Bogler, R. (2001), "The influence of leadership style on teacher job satisfaction", Educational Administration Quarterly, Vol. 37, pp. 662-83.

Cochran-Smith, M. (2004), "Stayers, leavers, lovers, and dreamers: insights about teacher retention", Journal of Teacher Education, Vol. 55, pp. 387-92.

Cranny, C.J., Smith, P.C. and Stone, E.F. (1992), Job Satisfaction: How People Feel About Their Jobs and How it Affects Their Performance, Lexington Books, New York, NY.

Curtin, T.R., Ingels, S.J., Wu, S. and Heuer, R. (2002), NELS: 88 Base Year to Fourth Follow-up Data File User's Manual (NCES 2002-323), US Department of Education, National Center for Education Statistics, US Government Printing Office, Washington, DC.

Dawis, R.V. and Lofquist, L.H. (1984), A Psychological Theory of Work Adjustment, University of Minnesota Press, Minneapolis, MN.

Dilworth, M.E. (1990), Reading Between the Lines: Teachers and Their Racial/Ethnic Cultures, ERIC Clearinghouse on Teacher Education and American Association of Colleges for Teacher Education, Washington, DC.

Dinham, S. (1995), "Time to focus on teacher satisfaction", Unicorn, Vol. 21 No. 3, pp. 64-75.

Dvorak, J. and Phillips, K.D. (2001), "Job satisfaction of high school journalism educators", paper presented at the Annual Meeting of the Association for Education in Journalism and Mass Communication.

Erez, A. and Judge, T.A. (2001), "Relationship of core self-evaluations to goal setting, motivation, and performance", Journal of Applied Psychology, Vol. 86, pp. 1270-9.

Firestone, W.A. and Pennell, J.R. (1993), "Teacher commitment, working conditions, and differential incentive policies", Review of Educational Research, Vol. 63, pp. 489-525.

Fritzsche, B.A. and Parrish, T. (2005), "Theories and research on job satisfaction", in Brown, S.D. and Lent, R.W. (Eds), Career Development and Counseling: Putting Theory and Research to Work, Wiley, Hoboken, NJ.

Gordon, J.A. (1993), "Why students of color are not entering teaching: reflections from minority students", Journal of Teacher Education, Vol. 45, pp. 346-53.

Greenhaus, J.H., Parasuraman, S. and Wormly, W.M. (1990), "Effects of race on organizational experiences, job performance evaluations, and career outcomes", Academy of Management Journal, Vol. 33, pp. 64-86.

Hansen, J.C. (2005), "Assessment of interests", in Brown, S.D. and Lent, R.W. (Eds), Career Development and Counseling: Putting Theory and Research to Work, Wiley, Hoboken, NJ.

Hart, P.M. (1994), "Teacher quality of work life: integrating work experiences, psychological distress and morale", Journal of Occupational and Organizational Psychology, Vol. 67, pp. 109-32.

Herzberg, F., Mausner, B. and Snyderman, B. (1959), The Motivation to Work, John Wiley and Sons Inc., New York, NY.

Heynes, B. (1988), "Educational defectors: a first look at teacher attrition in the NLS-72", Educational Researcher, Vol. 17, pp. 24-32.

Holland, P.W. and Thayer, D.T. (1986), Differential Item Functioning and the Mantel-Haenszel Procedure, ETS Research Report No. 86-31, Princeton, NJ. 
Hotchkiss, L. and Borow, H. (1996), "Sociological perspectives on work and career development", in Brown, D. and Brooks, L. (Eds), Career Choice and Development, 3rd ed., Jossey-Bass, San Francisco, CA, pp. 281-336.

Ingersoll, R.M. (2001), "Teacher turnover and teacher shortages: an organizational analysis", American Educational Research Journal, Vol. 38, pp. 499-534.

Judge, T.A., Erez, A., Bono, J.E. and Thoresen, C.J. (2002), "Do the traits self-esteem, neuroticism, locus of control, and generalized self-efficacy indicate a common core construct?", Journal of Personality and Social Psychology, Vol. 83, pp. 693-710.

Lee, J.B., Clery, S.B. and Presley, J.B. (2001), Path to Teaching, Illinois Education Research Council, Southern Illinois University, Edwardsville, IL.

Lent, R.W. (2005) "A social cognitive view of career development and counseling" in Brown, S.D. and Lent, R.W. (Eds), Career Development and Counseling: Putting Theory and Research to Work, Wiley, Hoboken, NJ.

Lent, R.W. and Brown, S.D. (2003), "A social cognitive model of educational and vocational satisfaction", unpublished manuscript, University of Maryland, College Park, MD.

Lent, R.W., Brown, S.D. and Hackett, G. (1994), "Toward a unifying social cognitive theory of career and academic interest, choice and performance", Journal of Vocational Behaviors, Vol. 45, pp. 79-122.

Ma, X. and MacMillan, R.B. (1999), "Influences of workplace conditions on teachers' job satisfaction", The Journal of Educational Research, Vol. 93 No. 1, pp. 39-47.

Mau, W.C. (2003), "Factors influencing persistence in science and engineering career aspirations", Career Development Quarterly, Vol. 51, pp. 234-43.

Mau, W.C. and Bikos, L.H. (2000), "Educational and vocational aspirations of minority and female students: a longitudinal study", Journal of Counseling and Development, Vol. 78, pp. 186-94.

Mau, W.C. and Mau, Y-H. (2006), "Factors influencing high school students to persist in aspirations of teaching careers: a longitudinal study", Journal of Career Development, Vol. 32, pp. 234-49.

Mertler, C.A. (2002), "Job satisfaction and perception of motivation among middle and high school teachers", American Secondary Education, Vol. 31, pp. 43-53.

Mueller, C.W., Finley, A., Iverson, R.D. and Price, J.L. (1999), "The effects of group racial composition on job satisfaction, organizational commitment, and career commitment", Work and Occupations: An International Sociological Journal, Vol. 26, pp. 187-219.

National Center for Educational Statistics (1990), National Education Longitudinal Study of 1988, Base Year: Student Component Data File User's Manual, Report No. 90-464, US Department of Education, Washington DC.

National Center for Educational Statistics (1991), Psychometric Report for the NELS: 88: Base Year Test Battery, Report No. 91-468, US Department of Education, Washington DC.

National Center for Educational Statistics (1994), National Educational Longitudinal Study, 1988: Second Follow-up (1992), Report No. 94-374, US Department of Education, Washington DC.

National Center for Educational Statistics (1997), A Note from the Chief Statistician: Technical Approaches to Performing Regression and other Multivariable Techniques on NCES Survey Data, Notes No. 3, US Department of Education, Washington DC.

Ostroff, C. (1992), "The relationship between satisfaction, attitudes, and performance: an organizational analysis", Journal of Applied Psychology, Vol. 77, pp. 93-974.

Page, J., Page, F., Hawk, J.D., Amburgey, B. and Correro, G. (1980), "The teaching profession", ERIC Document Reproduction Service No. ED346082.

Page, J.A. and Page, F.M. Jr (1984), "High school senior perception of teaching as a career opportunity", ERIC Document Reproduction Service No. ED241534.

Place, A.W. (1997), "Career choice of education: Holland type, diversity, and self-efficacy", Journal for a Just and Caring Education, Vol. 3, pp. 203-14. 
Schutz, P.A., Crowder, K.C. and White, V.E. (2001), "The development of a goal to become a teacher", Journal of Educational Psychology, Vol. 93, pp. 229-308.

Shreeve, W.C., Norby, J.R., Goeter, W.G.J., Stueckle, A.F., Midgley, T.K. and Goetter, P.S. (1988), "Job satisfaction: an imperative for the coming teacher shortage", Early Child Development and Care, Vol. 36, pp. 181-95.

Smith, P.C., Kendall, L.M. and Hulin, C.L. (1969), The Measurement of Satisfaction in Work and Retirement, Rand McNally, Chicago, IL.

Tracey, T.J.G., Robins, S.B. and Hofsess, C.D. (2005), "Stability and change in interests: a longitudinal study of adolescents from grades 8 through 12", Journal of Vocational Behavior, Vol. 66, pp. 1-25.

Tuch, S.A. and Martin, J.K. (1991), "Race in the workplace: black/white differences in the sources of job satisfaction", Sociological Quarterly, Vol. 32, pp. 13-116.

US Department of Education (2002), Meeting the Highly Qualified Teachers Challenge: The Secretary's Annual Report on Teacher Quality, US Department of Education, Washington, DC.

Vance, V.S. (1981), Analysis of Entry to Teaching Utilizing National Longitudinal Study Data, Report No. NIE-P-81-0100, National Institute of Education, Washington, DC, ERIC Document Reproduction Service No. ED237490.

Vegas, E., Murnane, R.J. and Willett, J.B. (2001), "From high school to teaching: many steps, who makes it?", Teachers College Record, Vol. 103, pp. 427-49.

Wu, V. and Short, P.M. (1996), "The relationship of empowerment to teacher job commitment and job satisfaction", Journal of Instructional Psychology, Vol. 23, pp. 85-9. 